Kemudi: Jurnal Ilmu Pemerintahan | 239

Volume 05 Nomor 02 Februari 2021

2622-9633 (Online)

Open Access at: https://ojs.umrah.ac.id/index.php/kemudi

DOI: https://doi.org/10.31629/kemudi.v5i02.3141

\title{
Analisis Faktor-Faktor Penentu Tata Kelola Pemerintahan Di Pemerintah Kota Surabaya Periode Kepemimpinan Tri Risma Harini Tahun 2015-2020
}

\author{
Muhammad Quranul Kariem \\ Dosen Ilmu Pemerintahan, Fakultas Ilmu Pemerintahan dan Budaya \\ Universitas Indo Global Mandiri \\ mquranul@uigm.ac.id \\ Noor Ishmatuddin \\ Prodi Ilmu Pemerintahan, Fakultas Ilmu Pemerintahan dan Budaya \\ Universitas Indo Global Mandiri \\ ishmatuddin noor@yahoo.com
}

\begin{abstract}
ABSTRAK
Pemerintah Kota Surabaya dibawah kepemimpinan Tri Risma Harini pada periode 2015-2020 menunjukkan berbagai keberhasilan dengan indikatorindikator dari sektor ekonomi, pembangunan, hingga lingkungan hidup. Metode penelitian yang digunakan dalam kajian ini adalah metode deskriptif kualitatif dengan pendekatan literature review. Hasil penelitian menunjukkan bahwa beberapa faktor internal maupun eksternal pemerintahan sangat mempengaruhi pembangunan tata kelola pemerintahan yang baik, yang berdampak pada keberhasilan pemerintahan.
\end{abstract}

\section{Kata Kunci: Tata Kelola Pemerintahan, Faktor, Dampak}

\section{Pendahuluan}

Tri Risma Harini terpilih kembali menjadi Walikota Surabaya periode kedua pada 2015-2020 di Pemilihan Kepala Daerah serentak tahun 2015. Risma dianggap sebagai salah satu kepala daerah yang berhasil pada periodesasi kepemimpinan di Pemerintah Kota Surabaya dengan meraih penghargaan walikota terbaik ketiga di dunia versi World Mayor pada tahun 2015 (tempo.co, 2015). Keberhasilan tersebut berdampak pada implementasi tata kelola pemerintahan yang baik di Pemerintah Kota Surabaya untuk mencapai tujuan secara efektif dan efisien.

Tata Kelola Pemerintahan yang baik akan mendorong perumusan dan implementasi program-program pemerintah yang berdampak pada masyarakat di kehidupan ekonomi dan pembangunan manusia. Indikator-indikator keberhasilan pemerintah kota surabaya dapat dilihat dari berbagai aspek, yaitu diantaranya adalah penurunan area banjir di Kota Surabaya dari 50\% menjadi $2 \%$, penurunan volume sampah menuju ke Tempat Pembuangan Akhir (TPA) dengan menerapkan program 3R (Reduce, Reuse, Recycle), peningkatan daya 
beli masyarakat dari $13 \%$ pada tahun 2010 menjadi 47\% pada tahun 2017, serta peningkatan jumlah wisatawan dari 15 Juta pada tahun 2015 menjadi 27 Juta pada tahun 2018 (liputan6.com, 2019). Tidak hanya itu, keberhasilan pemerintah kota surabaya juga dapat dilihat pada tahun 2018, dimana pertumbuhan ekonomi meningkat dari 5,80\% pada tahun 2015 menjadi 6,20\% pada tahun 2018 (bps.go.id, 2019). Pertumbuhan ekonomi ini melebihi pertumbuhan ekonomi nasional yang hanya tumbuh sekitar lima persen pada tahun tersebut.

Indikator-indikator lain yang menjadi bukti keberhasilan Pemerintah Kota Surabaya berdasarkan data yang dirilis oleh Badan Pusat Statistik (BPS) Kota Surabaya (2020) adalah indeks pembangunan manusia yang pada tahun 2017 pada angka 81,07 menjadi 82,22 pada tahun 2019. Selanjutnya, penurunan angka kemiskinan dari 5,82\% pada tahun 2015 menjadi 4,51\% pada tahun 2019 serta gini ratio (indeks kesenjangan sosial) yang angkanya semakin baik dari 0,42 pada tahun 2015 menjadi 0,39 pada tahun 2017 . Pemerintah Kota Surabaya juga telah membangun toko kelontong berbentuk koperasi di 9 rumah susun dan melakukan pembinaan terhadap 526 toko kelontong yang dipersiapkan menjadi bentuk koperasi. Pendapatan Asli Daerah (PAD) Kota Surabaya juga meningkat dari hanya Rp. 908 Milyar menjadi hampir Rp. 5 Triliun pada tahun 2018. Aspek infrastruktur pemerintah kota surabaya telah membangun 58 waduk dan kebun raya mangrove sebanyak 2.800 hektar, dan pembangunan jalan baru sepanjang $315 \mathrm{~km}$ (antaranews.com, 2018).

Beberapa aspek keberhasilan dari sektor ekonomi hingga lingkungan hidup tersebut, menjadi bukti bahwa tercapaianya implementasi tata kelola pemerintahan yang baik yang dilandasi oleh kekuatan kepemimpinan Tri Risma Harini di Pemerintah Kota Surabaya. Oleh karena itu, berpijak pada indikatorindikator keberhasilan pemerintah kota surabaya tersebut menarik untuk mengkaji sejauh mana faktor-faktor tata kelola pemerintahan berpengaruh dalam keberhasilan Pemerintah Kota Surabaya dibawah kepemimpinan Tri Risma Harini pada periode 2015-2020.

\section{Tinjauan Pustaka}


Terdapat berbagai penelitian mengenai faktor-faktor yang mempengaruhi tata kelola pemerintahan, pertama kajian dari Putra (2017) mengungkapkan bahwa tranparansi anggaran, keterbukaan informasi, dan akuntabilitas dalam tata kelola pemerintahan harus ditingkatkan. Penelitian dari Wibawa (2019) juga mengungkapkan hal yang hampir sama, bahwa keterbukaan informasi akan dapat mewujudkan tata kelola pemerintahan yang baik karena nilai tersebut merupakan bagian dari konsep tersebut. Penelitian dari Muslih, dkk (2019) menegaskan bahwa tata kelola pemerintah yang dibangun akan berdampak pada kinerja pemerintahan.

Penelitian dari Taufiq, dkk (2019) menemukan hal lain, yaitu bahwa interaksi dan sinergi yang efektif dan optimal dalam pemerintahan akan dapat diwujudkan dengan menerapkan e-governance. Penelitian yang dilakukan Yuwono, dkk (2020) juga berhubungan dengan penelitian tersebut, yaitu menemukan bahwa inovasi informasi dan teknologi yang dilakukan pemerintah dapat berdampak pada perubahan dalam banyak aspek di dalam pemerintahan serta memunculkan inovasi-inovasi lain-nya. Berdasarkan beberapa penelitian tersebut, maka dapat disimpulkan bahwa tata kelola pemerintahan yang baik dapat berdampak positif bagi pemerintahan yang diwujudkan dengan melakukan inovasi, membuka informasi serta penggunaan teknologi informasi.

Berdasarkan kajian pustaka yang telah dilakukan maka pendekatan teori yang akan digunakan dalam kajian ini adalah teori Yuwono (2014) yang menguraikan mengenai faktor-faktor yang menentukan keberhasilan tata kelola pemerintahan. Terdapat lima faktor yang diuraikan dalam teori ini yaitu, faktor pertama adalah pemimpin dan kepemimpinan, dimana individu menjadi penentu terjadinya perubahan serta gaya kepemimpinan yang efektif untuk tata kelola pemerintahan yang baik adalah gaya entrepreneurship. Faktor kedua adalah kelembagaan, dimana indikator dalam faktor ini adalah restrukturisasi atau perubahan struktur kelembagaan dalam pemerintah mempengaruhi keberhasilan tata kelola pemerintahan. Faktor ketiga adalah modernisasi sektor publik dimana dalam mewujudkan tata kelola pemerintahan yang baik yaitu dengan melakukan cara-cara baru (inovasi) serta penggunaan teknologi. 
Faktor keempat adalah mengenai masyarakat sipil yang terorganisir, bahwa harus ada partisipasi publik dan kontrol publik untuk meningkatkan efektifitas dari tata kelola pemerintahan. Faktor kelima adalah mengenai budaya atau tradisi demokrasi dimana setiap perubahan yang dilakukan harus mendapatkan dukungan dan penerimaan yang positif dari masyarakat, selain itu pemilihan umum yang kompetitif juga akan berkontribusi besar dalam tata kelola pemerintahan yang baik.

Kajian ini akan menggunakan pendekatan teori dari Yuwono mengenai faktor-faktor yang menentukan tata kelola pemerintahan yang baik. Teori tersebut diharapkan mampu menguraikan secara deskriptif berbagai variabel keberhasilan-keberhasilan yang telah dicapai oleh pemerintah kota surabaya selama periodesasi kepemimpinan Tri Risma Harini pada 2015-2020. Teori tersebut juga diharapkan dapat menganalisis secara mendalam terkait dengan konteks keberhasilan pemerintah dalam sudut pandang tata kelola pemerintahan yang baik.

\section{Metode Penelitian}

Metode Penelitian dalam kajian ini adalah metode deskriptif kualitatif dengan pendekatan literature review, dimana metode ini akan menguraikan mengenai teori, temuan, dan bahan penelitian lain-nya dimana uraian tersebut akan menjadi bahan perumusan dalam menyusun kerangka-kerangka pemikiran yang dihasilkan dalam kajian ini (Rahayu, dkk, 2019). Metode ini dipilih karena indikator-indikator dalam penelitian baik teori yang digunakan dan data dalam penelitian yang secara konsep akan relevan untuk menghasilkan kerangka pemikiran yang dapat dipahami melalui analisis dan simpulan yang dituliskan.

\section{Pembahasan}

Keberhasilan kepemimpinan Tri Risma Harini yang dilakukan di Pemerintah Kota Surabaya pada periode 2015-2020 akan diuraikan berdasarkan indikator-indikator keberhasilan yang akan dianalisis menggunakan pendekatan teoritis lima faktor-faktor yang mempengaruhi tata kelola pemerintahan dari Yuwono. Analisis tersebut dikorelasikan pada konteks Pemerintah Kota Surabaya dibawah kepemimpinan Walikota Tri Risma Harini 
pada periode 2015-2020. Faktor pertama adalah pemimpin dan kepemimpinan, dimana dalam konteks pemimpin sebagai seorang individu Tri Risma Harini mempunyai karakter sebagai individu yang memiliki etika kepedulian terhadap orang-orang yang ada disekitarnya (Jena, 2016).

Etika kepedulian yang dimiliki oleh Tri Risma Harini menjadi karakter yang melekat pada-nya saat melaksanakan tugas dan fungsi sebagai Walikota Surabaya. Karakter sebagai pribadi dalam kehidupan rumah tangga dan karakter sebagai pejabat publik tidak dapat didikotomikan, karena kedua-nya merupakan satu kesatuan. Selanjutnya adalah gaya kepemimpinan, dalam perspektif teori Yuwono bahwa gaya kepemimpinan yang efektif untuk mewujudukan tata kelola pemerintahan yang baik adalah gaya kepemimpinan entrepreneur, dalam hal ini berdasarkan penelitian dari Tuti \& Adawiyah (2020) menemukan bahwa gaya kepemimpinan Tri Risma Harini sebagai Walikota Surabaya mempunyai tipe kepemimpinan bureaucratic entrepreneur yang demokratis dan memiliki empati. Hal tersebut secara langsung menegaskan bahwa gaya kepemimpinan yang ia miliki sesuai dengan prasyarat untuk mewujudkan sebuah tata kelola pemerintahan yang baik. Oleh karena itu, dalam kapasitasnya sebagai individu dan sebagai Walikota Surabaya bahwa faktor pertama mengenai pemimpin dan kepemimpinan untuk mewujudkan tata kelola pemerintahan yang baik dapat terpenuhi.

Faktor kedua adalah faktor kelembagaan, dimana dalam hal ini pemerintah kota surabaya melakukan perubahan sturktur kelembagaan pemerintah-nya pada tahun 2016 yang lalu. Adapun perubahan kelembagaan yang dilakukan oleh pemerintah kota surabaya adalah mengurangi jumlah asisten di Sekretariat Daerah dari empat menjadi tiga, perubahan juga terjadi pada dua organisasi perangkat daerah yang ditambah tugasnya yaitu menjadi Dinas Pekerjaan Umum, Bina Marga, dan Pematusan serta Dinas Kebersihan dan Ruang Terbuka Hijau. Adapun organisasi perangkat daerah lain yang ditambahkan tugasnya adalah Dinas Perumahan Rakyat dan Kawasan Permukiman, Cipta Karya dan Tata Ruang. Selanjutnya terdapat penambahan lima organisasi perangkat daerah yang baru yaitu Badan Perencanaan, Badan Pendapatan dan Pengelolaan Keuangan, Badan Kepegawaian dan Pelatihan, Badan Penanggulangan Bencana dan Perlindungan Masyarakat, serta Badan Kesatuan Bangsa dan Politik (detik.com, 2016). 
Perubahan organisasi perangkat daerah tersebut secara tidak langsung menjadi bukti adanya fleksibilitas organisasi untuk mencapai tujuan-tujuan yang ditetapkan oleh Pemerintah Kota Surabaya dan DPRD Kota Surabaya. Berdasarkan beberapa capaian pemerintah di bidang lingkungan hidup yang telah diurakan sebelumnya, bahwa perubahan organisasi berhubungan dengan keberhasilan pemerintah menyelesaikan persoalan-persoalan tersebut. Artinya bahwa faktor kedua dalam konsep teoritis ini terpenuhi oleh Pemerintah Kota Surabaya dan DPRD yang telah melakukan perubahan-perubahan pada struktur kelembagaan-nya.

Faktor ketiga yaitu modernisasi sektor publik, dimana pemerintah harus melakukan inovasi-inovasi serta penggunaan teknologi informasi untuk mewujudkan tata kelola pemerintahan yang baik. Dalam hal ini pemerintah kota surabaya telah membuat setidaknya tiga inovasi pelayanan publik yang telah masuk dalam Top 99 Sistem Inovasi Pelayanan Publik (SINOVIK) Kementerian Pendayagunaan Aparatur Negara dan Reformasi Birokrasi, yaitu diantaranya adalah Pelayanan Publik 6 in 1 dimana pelayanan ini mengintegrasikan berbagai layanan kependudukan secara online, yang kedua adalah Inovasi Tahu Panas (Tak Takut Hujan dan Tak Takut Kepanasan) yang merupakan program perbaikan rumah yang tidak layak huni pada pemukiman kumuh, dan yang ketiga inovasi pahlawan ekonomi dan pejuang muda untuk memberikan pelatihan, pendampingan, pemasaran, pengemasan, promosi, dan pemasaran produk bisnis usaha kecil menengah kepada ibu-ibu dan anak muda (surabaya.go.id, 2018).

Pemerintah Kota Surabaya juga mengembangkan berbagai aplikasi dalam pemerintahan atau sistem e-Government yaitu diantaranya adalah Sistem Pengelolaan Keuangan Daerah yang merupakan aplikasi keuangan daerah, selanjutnya e-SDM yaitu adalah aplikasi untuk para Aparatur Sipil Negara di lingkungan Pemerintah Kota Surabaya, selanjutnya adalah e-Permit yaitu aplikasi untuk mengurus segala jenis perizinan, selanjutnya adalah eEducation adalah aplikasi untuk pendidikan bagi pelajar dan orang tua wali. Aplikasi yang selanjutnya adalah e-Health yaitu untuk memudahkan pasien dalam mengakses layanan kesehatan, serta Command Center Siaga Bencana yang mengkontrol lebih dari 2.000 titik CCTV untuk mengawasai kota surabaya dari berbagai hal darurat (menpan.go.id, 2017). 
Inovasi dan penggunaan teknologi yang telah dilakukan oleh Pemerintah Kota Surabaya dibawah kepemimpinan Tri Risma Harini sebagai Walikota pada praktiknya telah memenuhi indikator pada faktor modernisasi sektor publik yang dimaksudkan dalam perspektif teori ini. Faktor keempat adalah faktor masyarakat sipil yang terorganisir, yaitu dibuktikan dengan tinggi-nya angka partisipasi masyarakat dalam program-program yang dimiliki oleh Pemerintah Kota Surabaya. Pertama pemerintah kota surabaya membangun Media Center yang pada akhir tahun 2015 jumlah aduan yang masuk dan dapat direspon totalnya adalah 2.546 aduan (surabaya.go.id, 2015). Selanjutnya, Commad Center 112 yang dimiliki oleh pemerintah Kota Surabaya sejak tahun 2016 pasca dirilis, terdapat 46 aduan masyarakat yang telah ditangani, pada tahun 2017 terdapat peningkatan tajam aduan dan tercatat 3.602 aduan telah berhasil ditangani, aduan tersebut meliputi kebakaran, bencana alam, penemuan jenazah, bangunan roboh, penerangan jalan, kriminalitas, kekerasan dalam rumah tangga, dan aduan keamanan dan ketertiban lain-nya (Shodiqien, 2018).

Hal tersebut membuktikan bahwa tingkat partisipasi dan kontrol masyarakat dalam setiap persoalan publik sangat tinggi yang menunjukkan kesadaran masyarakat yang baik. Kondisi tersebut juga dikonfirmasi oleh lembaga pengawas eksternal yaitu Ombudsman Republik Indonesia Kantor Perwakilan Provinsi Jawa Timur yang mencatat mayoritas aduan 50,65\% atau sebanyak 205 laporan berasal dari masyarakat Kota Surabaya selama tahun 2018 (ombudsman.go.id, 2019). Tidak hanya itu, bentuk partisipasi masyarakat juga diaplikasikan dalam keikutsertaan dalam kaderisasi lebih dari 29.000 kader lingkungan pengelolaan limbah dari berbagai elemen masyarakat (liputan6.com, 2019). Masyarakat teroganisir yang memiliki tingkat kesadaran partisipasi dan kontrol yang tinggi, pada konteks teoritis tersebut berdasarkan bukti-bukti empiris dalam beberapa kasus telah terpenuhi dalam rangka mewujudkan tata kelola pemerintahan yang baik.

Faktor kelima adalah tradisi atau budaya politik, bahwa secara sosiologi masyarakat menerima setiap perubahan-perubahan yang dilakukan oleh pemerintah dibawah kepemimpinan Tri Risma Harini. Hal tersebut dibuktikan dengan tingkat partisipasi masyarakat yang tinggi dalam persoalan yang dihadapi, yang telah diuraikan sebelumnya serta tingkat kepuasan yang tinggi terhadap pemerintah. Lembaga Survei SMRC melakukan survei pada 11-18 
November 2020 dengan jumlah 820 responden, yang menghasilkan tingkat kepuasan masyarakat terhadap kinerja Tri Risma Harini dalam kapasitasnya sebagai Walikota Surabaya adalah sebesar 97\% (kumparan.com, 2020). Data tersebut juga dikonfirmasi oleh survei indeks kepuasan masyarakat pada 154 kelurahan pada tahun 2019 di Kota Surabaya yang menunjukkan hasil Baik (B) dengan nilai 79,99 (surabaya.go.id, 2019). Statistik tersebut dapat diartikulasikan sebagai tingkat penerimaan masyarakat dan tinggi terhadap setiap perubahan maupun terobosan yang dilakukan oleh Pemerintah Kota Saurabaya dibawah kepemimpinan Tri Risma Harini.

Selain daripada penerimaan masyarakat yang tinggi terhadap setiap perubahan yang dilakukan, pada hakekatnya kepercayaan tersebut didapatkan dari proses politik yaitu pemilihan kepala daerah serentak tahun 2015 yang lalu, yang dimana Tri Risma Harini dan Wishu Sakti Buwono sebagai incumbent dalam pemilihan tersebut memenangkan $86,34 \%$ atau 893.087 suara mengalahkan penantang-nya yang hanya meraih $13,66 \%$ atau 141.324 suara (detik.com, 2015). Legitimasi mayoritas yang diraih oleh Tri Risma Harini pada kontestasi politik merefleksikan kepercayaan masyarakat yang tinggi kepadanya yang secara langsung juga berdampak pada Pemerintah Kota Surabaya. Sehingga terdapat korelasi antara kepercayaan masyarakat dalam kontestasi politik dengan kepuasan masyarakat terhadap kinerja Tri Risma Harini dalam pemerintahan. Berdasarkan data-data tersebut, maka dapat dinyatakan bahwa faktor kelima mengenai tradisi atau budaya politik terpenuhi dengan baik.

\section{Kesimpulan Dan Saran}

Pemerintah Kota Surabaya pada kepemimpinan Tri Risma Harini periode 2015-2020 menunjukkan bahwa lima faktor yang menentukan tata kelola pemerintahan yang baik telah terpenuhi berdasarkan data-data empiris serta analisa yang telah diurakan dalam pembahasan. Hal tersebut berarti bahwa Pemerintah Kota Surabaya memiliki tata kelola pemerintahan yang baik yang berdampak pada keberhasilan-keberhasilan pemerintah pada berbagai sektor. Berdasarkan perspektif teoritis, temuan dalam kajian ini adalah bahwa faktorfaktor tersebut mempunyai peran strategis dalam mentransformasi tata kelola pemerintahan sehingga mampu menjawab berbagai persoalan publik dengan baik. 
Saran dalam kajian ini adalah bahwa keberhasilan pemerintah kota surabaya dalam mencapai berbagai hal positif bagi masyarakat tidak terlepas dari pembangunan tata kelola pemerintahan yang baik, namun hal tersebut sangatlah dipengaruhi oleh pemimpin politik yang mempunyai karakter serta gaya kepemimpinan dan dukungan yang kuat dari masyarakat. Kondisi tersebut sebenarnya berpotensi mendegradasikan tata kelola pemerintahan yang sudah dibangun, oleh karena itu harus ada standarisasi kepemimpinan untuk menjaga kualitas tata kelola pemerintahan dan juga pemimpin harus mampu membangun dukungan masyarakat yang baik.

\section{DAFTAR PUSTAKA}

\section{Buku-buku}

Yuwono, Teguh. (2014). Faktor-Faktor yang Menentukan Tata Kelola Pemerintahan yang baik Kasus Pemerintah Daerah Kota Surakarta 2005-2014, Disertasi, Universitas Padjajaran : Bandung

\section{Jurnal}

Jena, Y. (2016). Watak Kepedulian dalam Kepemimpinan Walikota Surabaya, Tri Rismaharini. Jurnal Perkotaan, 8(1), 36-48.

Muslih, M., Rahadi, D. R., \& Marbun, S. O. (2019). Tata Kelola Pemerintahan Berkelanjutan Untuk Meningkatkan Kinerja Pemerintah Daerah. Konferensi Nasional IImu Administrasi, 3(1).

Putra, H. S. (2017). Tata Kelola Pemerintahan Desa Dalam Mewujudkan Good Governace Di Desa Kalibelo Kabupaten Kediri. Jurnal Politik Muda, 6(2), 110-119.

Rahayu, T., Syafril, S., Wekke, I. S., \& Erlinda, R. (2019). Teknik Menulis Review Literatur Dalam Sebuah Artikel IImiah.

Shodiqien, A. F. A. (2018). Inovasi Pelayanan Publik Melalui Command Center 112 Dalam Menangani Pengaduan Masyarakat Di Badan Penanggulanggan Bencana Dan Perlindungan Masyarakat (Bpb Linmas) Kota Surabaya. Kebijakan Dan Manajemen Publik, 6(1), 1-13.

Taufiq, O. H., Yuliani, D., \& Hermawandi, D. (2019). Tata Kelola Pemerintah Desa Berbasis E-Government Menuju Good Governance. Dinamika: Jurnal Ilmiah Ilmu Administrasi Negara, 6(1), 145-152.

Tuti, R. W. (2020). KEPEMIMPINAN WALIKOTA SURABAYA TRI RISMAHARINI SEBAGAI MODEL BIROKRASI EFEKTIF. Perspektif Komunikasi: Jurnal IImu Komunikasi Politik dan Komunikasi Bisnis, 4(1), 73-82.

Wibawa, K. S. (2019). Urgensi Keterbukaan Informasi dalam Pelayanan Publik sebagai Upaya Mewujudkan Tata Kelola Pemerintahan yang Baik. Adm. Law Gov. J, 2(2), 218-234.

Yuwono, T., Alfirdaus, L. K., \& Manar, D. G. (2020). Semua Berawal dari IT: Terobosan Banyuwangi dalam Menata Ulang Tatakelola Pemerintahan. Politika: Jurnal IImu Politik, 11(2), 148-162.

\section{Data Internet}


Risma Tempati Posisi 3 Walikota terbaik di dunia, lihat dalam: https://nasional.tempo.co/read/639648/risma-tempati-posisi-3-walikota-terbaik-dunia

Walikota Risma Pamer Keberhasilan Atasi Sampah dan Banjir di Forum UCLG, lihat dalam : https://surabaya.liputan6.com/read/4111493/wali-kotarisma-pamer-keberhasilan-atasi-sampah-dan-banjir-di-forum-uclg

Pertumbuhan Ekonomi Kota Surabaya Tahun 2018, lihat dalam : https://surabayakota.bps.go.id/pressrelease/2019/09/03/129/pertumb uhan-ekonomi-kota-surabaya-tahun-2018.html

Badan Pusat Statistik Kota Surabaya, lihat dalam : https://surabayakota.bps.go.id/

Progres Pembangunan Surabaya Selama 2018, lihat dalam : https://www.antaranews.com/berita/776733/progres-pembangunankota-surabaya-selama-2018

Raperda OPD diputuskan, ini Perubahan Struktur Dinas Pemkot Surabaya, lihat dalam : https://news.detik.com/berita-jawa-timur/d-3310166/raperdaopd-diputuskan-ini-perubahan-struktur-dinas-pemkot-surabaya

3 Terobosan Surabaya Masuk Top 99 Sistem Inovasi Pelayanan Publik https://humas.surabaya.go.id/2018/07/19/3-terobosan-surabayamasuk-top-99-sistem-inovasi-pelayanan-publik-kemenpan-rb/

Best Prarice E-Government Surabaya, Walikota Risma Paparkan Resep Sistem Tata Kelola Pemerintah Yang Ideal, lihat dalam : https://www.menpan.go.id/site/berita-terkini/best-practice-egovernment-surabaya-walikota-risma-paparkan-resep-sistem-tatakelola-pemerintah-yang-ideal

Laporan Kinerja Dinas Komunikasi dan Informatika Kota Surabaya, lihat dalam : www.diskominfo.surabaya.go.id

Jumlah Laporan di Surabaya Teringgi, lihat dalam : https://ombudsman.go.id/perwakilan/news/r/pwk--jumlah-laporan-disurabaya--tertinggi

Survei SMRC : 97\% Warga Surabaya Puas dengan Kinerja Risma, lihat dalam : https://kumparan.com/kumparannews/survei-smrc-97warga-surabaya-puas-dengan-kinerja-risma-1uddJJ1WFYU/full

Laporan Survey Indeks Kepuasan Masyarakat Bidang Pelayanan Umum di Surabaya Timur Tahun 2019, lihat dalam : https://organisasi.surabaya.go.id/home/file/pelayanan\%20publik/2019 LLaporan\%20Kelurahan\%20Surabaya\%20Timur.pdf

Kubu Penantang Risma Akhirnya Terima Hasil Pilkada Surabaya 2015, lihat dalam : https://news.detik.com/berita-jawa-timur/d3100130/kubu-penantang-risma-akhirnya-terima-hasil-pilkadasurabaya-2015 